\title{
Preferencja wartości a jakość i trwałość małżeństwa. Badanie żon Anonimowych Alkoholików
}

\section{Wstęp}

М /iększość istniejących społeczności opiera się na małżeństwie monogamicznym i nierozerwalnym (w znaczeniu: trwałym aż do śmierci jednego z współmałżonków). Są to założenia kluczowe ze względu na realizację zadań właściwych dla podstawowej komórki społecznej, jaką jest małżeństwo i rodzina. W rodzinie kształtowane są dojrzałe i prawidłowe zachowania, postawy i światopogląd, niezbędne do stworzenia i podtrzymania szczęśliwego małżeństwa. Obserwując jednak obecne tendencje światowe, uwagę zwraca niepokojący problem szybko wzrastającej liczby rozwodów. Dane Głównego Urzędu Statystycznego z 2018 r. informują, że przeszło 30\% małżeństw zawartych w Polsce rozpadło się, a 90\% badanych młodych osób w Polsce jest za możliwością udzielania rozwodów ${ }^{1}$. Widać zatem, że małżeństwo i rodzina przeżywa obecnie wiele trudności i kryzysów. Zadaniem badaczy byłoby zatem poszukiwanie czynników odpowiedzialnych za ten stan rzeczy. Życie w związku małżeńskim, jego jakość i trwałość uwarunkowane jest wieloma czynnikami. Sprawa wydaje się komplikować jeszcze bardziej, gdy próbujemy wniknąć w jakość i trwałość tych par, które przeżywają trudności związane

* Dr Dominika Zarosıńska - Katolicki Uniwersytet Lubelski Jana Pawła II, Katedra Psychologii Wychowawczej i Rodziny, email: dominika.zarosinska@gmail.com, ORCID 0000-0003-1088-798X

** Dr hab. Jacek Śliwak - Katolicki Uniwersytet Lubelski Jana Pawła II, Katedra Psychologii Społecznej i Psychologii Religii, email: sliwak@kul.lublin.pl, ORCID 0000-0002-7695-4113

${ }^{1}$ Niepublikowane badania CBOS, 2019. Por.: Rocznik Demograficzny, red. D. Rozkrut, Warszawa 2018. 
z chorobą alkoholową jednego z małżonków, albo gdy jedna z nich podejmuje próby leczenia i wyjścia z uzależnienia.

W tym artykule podjęto próbę poszukiwania powiązań między preferencją wartości i ich strukturą a jakością i trwałością małżeństwa, badając specyficzną grupę, jaką są żony Anonimowych Alkoholików. Zbadanie tej grupy, opisanie i wyjaśnienie związków między uznawanymi wartościami a jakością i trwałością związków małżeńskich, w jakich funkcjonują żony Anonimowych Alkoholików, może być istotnym wkładem do wiedzy na temat funkcjonowania uzależnionej rodziny.

Jakość i trwałość związków małżeńskich. Twórcami tych pojęć są Lewis i Spanier ${ }^{2}$. Definiują oni trwałość (stabilność) związku partnerskiego jako określenie relacji nierozerwalnej, stałej aż do śmierci jednego ze współmałżonków³. Spanier i Lewis zdefiniowali jakość małżeństwa jako „subiektywną ocenę związku pary małżeńskiej z uwzględnieniem pewnej liczby wymiarów i ocen”“4. Determinant ulepszających jakość związku literatura przedmiotu wymienia bardzo dużo. Do czynników psychospołecznych, warunkujących jakość i trwałość małżeństwa, zaliczane są na przykład: wzajemna akceptacja, szacunek, wzajemna miłość, tolerancja, podobieństwo pod względem przekonań i praktyk religijnych, zaakceptowanie zainteresowań współmałżonka, zdolność rozwiązywania konfliktów, zgodność z oczekiwaniami posiadanej liczby dzieci, wzajemna życzliwość, wzajemna szczerość, zbieżność istotnych poglądów i zgodność wobec ważnych norm moralnych, wzajemna uczciwość, poczucie zadowolenia i satysfakcji z małżeństwa, wzajemna wierność i otwartośćs. Należy zwrócić uwagę na fakt,

${ }^{2}$ R.A. Lewis, G.B. Spanier, Theorizing about the Quality and Stability of Marriage, w: Contemporary Theories about the Family. Research-Based Theories. Vol. 1, red. W.R. Burr, R. Hill, F.I. Nye, I.L. Reiss, New York 1979, s. 268-294.

${ }^{3}$ G.B. Spanier, R.A. Lewis, Marital Quality: a Review of the Seventies, „Journal of the Marriage and the Family" 1980, nr 4, s. 825-839. Zob. też: R.A. Lewis, G.B. Spanier, Theorizing about the Quality and Stability of Marriage..., s. 269.

${ }^{4}$ G.B. Spanier, R.A. Lewis, Marital Quality....

${ }_{5}^{5}$ T. Rostowska, Dojrzałość osobowa jako podstawowe uwarunkowanie życia małżeńskiego i rodzinnego, w: Psychologia w stużbie rodziny, red. I. Janicka, T. Rostowska, Warszawa 2003, s. 45-55. Zob. też: A. Chybicka, K. Karasiewicz, Zadowolenie z intymnych relacji oraz poczucie własnej atrakcyjności i komunikacji w związkach narzeczeńskich i małżeńskich, w: Psychologia rodziny. Małżeństwo i rodzina wobec wspótczesnych wyzwań, red. T. Rostowska, Warszawa 2009, s. 136-161; U. Dudziak, Seksualność - jako szczególny sposób i możliwość wyrażania miłości, w: Miłość i życie. Małżeństwo i rodzina w budowaniu cywilizacji miłości, red. M. Ryś, Z. Struzik, Warszawa 2015, s. 67-72; A. Peplińska, Psychologiczne i zdrowotne konsekwencje równoważenia ról zawodowych i rodzinnych, w: Zawodowe i zdrowotne problemy człowieka w różnych okresach dorosłości. Perspektywa psychologiczna, red. T. Rostowska, W. Budziński, Torun 2012, s. 64-85; T. Rostowska, Rozwojowe aspekty jakości życia rodzinnego, w: Jakość życia rodzinnego. Wybrane zagadnienia, red. T. Rostowska, Łódź 2006, s. 11-27; T. Rostowska, Aktywność zawodowa matżonków a jakość ich życia, w: Psychologia rodziny. Małżeństwo i rodzina wobec współczesnych wyzwań, red. T. Rostowska, Warszawa 2009, s. 60-80; T. Rostowska, Miłość małżeńska w perspektywie psychologicznej, w: Małżeństwo i miłość. Kontekst 
że wiele z wymienionych wyżej determinant warunkujących jakość małżeństwa należy do sfery wartości uznawanych przez osoby. Autorzy modelu jakości i trwałości małżeństwa - Lewis i Spanier - podkreślają również znaczenie uznawanej przez osobę hierarchii wartości w funkcjonowaniu małżeństwa ${ }^{6}$. Benedykt XVI w Encyklice o miłości chrześcijańskiej sugeruje, że na jakość i trwałość relacji międzyludzkich wpływają wartości uznawane przez osoby, takie jak umiejętność posługiwania drugiemu człowiekowi, wyrzeczenie i gotowość do poświęceń. Dojrzała relacja międzyludzka, trwała i o wysokiej jakości, poszukuje wyrzeczeń i poświęceń. Osoba, chcąc zbudować taką relację, musi nauczyć się na trwałe wychodzić poza własne „ja”. Trwała relacja jest możliwa wówczas, gdy osoba coraz mniej pytań stawia o siebie samego, coraz bardziej szuka szczęścia drugiej osoby i troszczy się o nią.

Problematyka wartości jest obecna w wielu dyscyplinach naukowych, między innymi w filozofii, teologii, socjologii, antropologii kulturowej, pedagogice oraz w psychologii. Jedną z najpopularniejszych w tej ostatniej jest teoria wartości Shaloma Schwartza7. Schwartz definiuje wartości następująco: „jest to poznawcza reprezentacja (zwykle przekonanie) motywacyjnego, godnego pożądania, ponadsytuacyjnego celu". Innymi słowy, wartości odgrywają decydującą rolę jako centralne z punktu widzenia osoby, najważniejsze reguły postępowania w życiu, istniejące jako cele bez względu na sytuacje`. Schwartz ukazuje strukturę

psychologiczny i neuropsychologiczny, red. J. Rostowski, T. Rostowska Warszawa 2014, s. 289-335; T. Rostowska, J. Rostowski, Miłość jako wyznacznik jakości małżeńskiej, w: Rodzina - rozwój-praca. Wybrane zagadnienia, red. T. Rostowska, J. Rostowski, Łódź 2002, s. 9-21; T. Rostowska, P. Żylińska, Stopień zaangażowania religijnego a poziom jakości małżeńskiej u partnerów, w: Psychologia rodziny. Małżeństwo i rodzina wobec współczesnych wyzwań, red. T. Rostowska, Warszawa 2009, s. 117-135; J. Rostowski, Podobieństwo w zakresie sześciowymiarowego modelu dobranego zwiazku małżeńskiego w ujęciu J. Rostowskiego (KDM-1), w: Małżeństwo i miłość. Kontekst psychologiczny i neuropsychologiczny, red. J. Rostowski, T. Rostowska, Warszawa 2014, s. 88-152; J. Rostowski, T. Rostowska, Poziom zdrowia i dobrego samopoczucia jako następstwa konfliktu lub integracji relacji praca-rodzina, w: Zawodowe i zdrowotne problemy człowieka w różnych okresach dorosłości. Perspektywa psychologiczna, red. T. Rostowska, W. Budziński, Torun 2012, s. 11-37; M. Ryś, Jakość i trwałość małżeństwa...; M. Ryś, Wspieranie rozwoju osobowego $w$ rodzinie, $\mathrm{w}$ : $W$ trosce o rodzinę. W poszukiwaniu prawdy, dobra i piękna, red. M. Ryś, M. Jankowska, Warszawa 2007, s. 25-40; G.B. Spanier, Measuring Dyadic Adjustment: New Scales for Assessing the Quality of Marriage and Similar Dyads, „Journal of the Marriage and the Family" 1976, nr 1, s. 15-28; G.B. Spanier, R.A. Lewis, Marital Quality...; M. Wolan-Nowakowska, Praca zawodowa a jakość małżeńska, w: Psychologia w służbie rodziny, red. I. Janicka, T. Rostowska, Łódź 2003, s. 109-117.

${ }^{6}$ R.A. Lewis, G.B. Spanier, Theorizing about the Quality and Stability of Marriage....

7 J. Śliwak, Altruizm a preferencja wartości - badania empiryczne, „Roczniki Filozoficzne” 1996, nr 4, s. 111-146.

${ }^{8} \mathrm{~J}$. Cieciuch, Kształtowanie się systemu wartości od dzieciństwa do wczesnej dorosłości, Warszawa 2013, s. 37.

9 J. Śliwak, M. Kruk, B. Zarzycka, Preferencja wartości a postawa wobec adopcji, w: Dalej w te samą stronę: księga jubileuszowa dedykowana profesor Marii Braun-Gałkowskiej, red. I. Ulfik-Jaworska, A. Gała, Lublin 2012, s. 209-222. 
wartości człowieka w formie kołowego kontinuum - jako uniwersalnego i motywacyjnego (por. rys. 1) 10. Schwartz, analogicznie do ujęcia Rokeacha, uznaje, że osobiste preferencje wartości przyjmują postać hierarchicznąal . Wymienia on dwie główne cechy struktury wartości: kontinuum i kołowośćc ${ }^{12}$. Kontinuum wiąże się z brakiem możliwości sztucznego podziału na odrębne jednostki, wyodrębnianie ich jest więc arbitralne. Drugą cechą struktury wartości jest to, że ma ona kształt koła. Oznacza to, że wartości sąsiadujące ze sobą są do siebie podobne. Z kolei wartości na przeciwległych stronach koła są wobec siebie niezgodne. Owo kontinuum jest motywacyjne - wartości usytuowane blisko siebie są motywacyjnie analogiczne, a zatem mogą być realizowane w jednym działaniu. Natomiast wartości niezgodne (z przeciwległych stron koła) są trudne lub niemożliwe do jednoczesnej realizacji, a ich konsekwencje są sprzeczne psychologicznie lub realnie ${ }^{13}$.

Cieciuch kontinuum wartości dzieli na 10 typów: przystosowanie, tradycja, życzliwość, uniwersalizm, kierowanie sobą, stymulacja, hedonizm, osiągnięcia, władza, bezpieczeństwo ${ }^{14}$. Typy te można opisać na czterech tzw. wartościach wyższego rzędu. Określają one krańce dwóch wymiarów, tworzących koło: przekraczanie siebie $v s$ umacnianie siebie oraz otwartość na zmiany $v s$ zachowawczość.

Model ten przedstawiony został poniżej na rysunku 1.

${ }^{10}$ J. Cieciuch, Pomiar wartości w zmodyfikowanym modelu Shaloma Schwartza, „Psychologia Społeczna" 2013, nr 1, s. 22-41.

${ }^{11}$ Tamże.

12 S.H. Schwartz, Universals in the content and structure of values: Theory and empirical tests in 20 countries, w: Advances in experimental social psychology. T. 25, red. M. Zanna, New York 1992, s. 1-65; S.H. Schwartz, Basic human values: Theory, measurement and application, „Revue Francaise de Sociologie" 2006, nr 4, s. 929-968. Zob. też: S.H. Schwartz et al., Refining the theory of basic individual values, „Journal of Personality and Social Psychology” 2012, nr 4, s. 663-688.

${ }^{13}$ S.H. Schwartz, Universals in the content and structure of values...; S.H. Schwartz, Basic human values.... Zob. też: P. Brzozowski, Uniwersalność struktury wartości: Koncepcja Shaloma H. Schwartza, „Roczniki Psychologiczne” 2002, 5, s. 27-51; S.H. Schwartz, J. Cieciuch, M. Vecchione, E. Davidov, R. Fischer, C. Beierlein, A. Ramos, M. Verkasalo, J.E. Lönnqvist, K. Demirutku, O. Dirilen-Gumus, M. Konty, Refining the theory...

${ }^{14}$ J. Cieciuch, Pomiar wartości..., s. 24; J. Cieciuch, Kształtowanie się systemu wartości..., s. 56-57, 60-62. Zob. też: J. Cieciuch, Z. Zaleski, Polska adaptacja Portretowego Kwestionariusza Wartości Shaloma Schwartza, „Czasopismo Psychologiczne” 2011, nr 2, s. 254. 


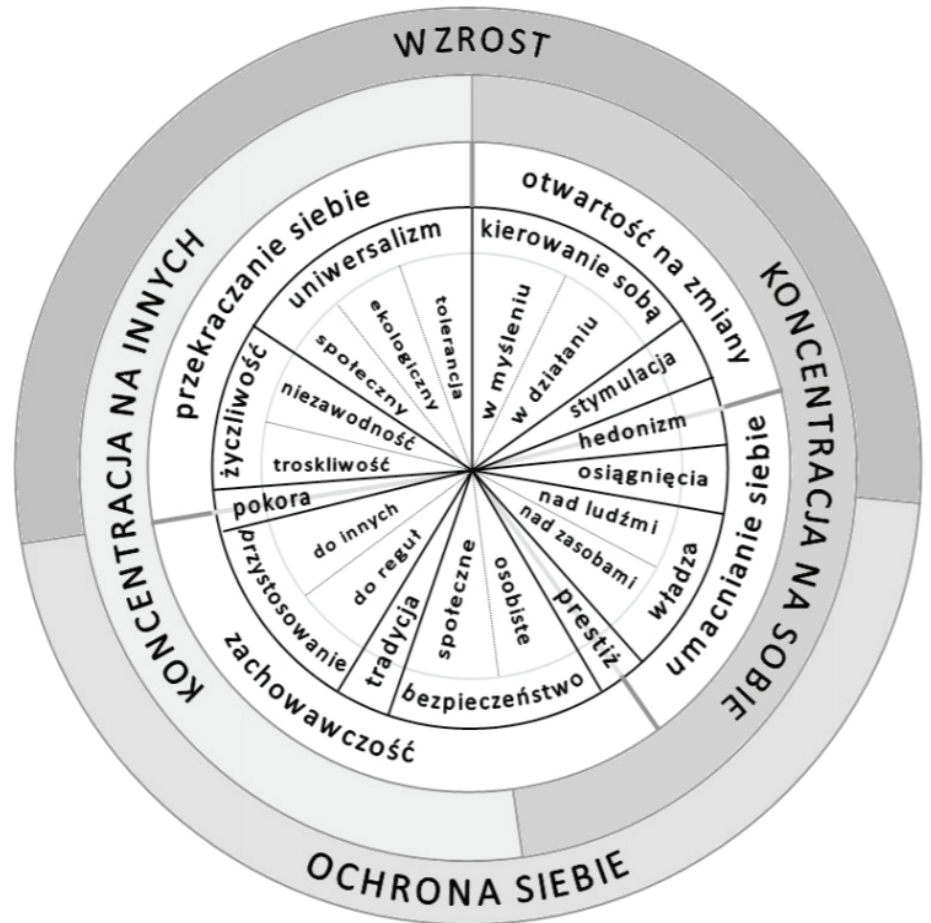

Na przekraczanie siebie składa się życzliwość (dbanie o dobro rodziny czy przyjaciół) oraz uniwersalizm (szacunek, tolerancja, zrozumienie oraz dobro ludzi i przyrody). Do umacniania siebie autor zalicza natomiast osiągnięcia (osobiste sukcesy, uzyskane dzięki własnym kompetencjom i w zgodzie ze społecznymi standardami), władzę (status, prestiż społeczny, dominację i kontrolowanie innych ludzi oraz ich zasobów) i częściowo hedonizm (przyjemność i zmysłowe zaspokojenie). Hedonizm, stymulacja (zmienność, nowość i podniecenie) oraz kierowanie sobą (niezależność myślenia, działania i wyborów, a także wolność i twórczość) wchodzą zaś w skład otwartości na zmianę. Składowymi zachowawczości są z kolei bezpieczeństwo (stabilizacja, porządek, pokój i harmonia), przystosowanie (ograniczanie swoich impulsów, działań i dążeń) oraz tradycja (akceptacja i podtrzymywanie zwyczajów, tradycji czy idei własnej rodziny, religii lub kultury $)^{16}$. Dodatkowo, autor podaje, iż wartości

${ }^{15}$ Por. J. Cieciuch, Pomiar wartości...

16 Tamże; J. Cieciuch, Kształtowanie się systemu wartości... Zob. też: J. Cieciuch, Z. Zaleski, Polska adaptacja... 
przekraczania siebie i zachowawczości tworzą obszar wartości skoncentrowanych na innych, podczas gdy wartości umacniania siebie i otwartości tworzą obszar wartości skoncentrowanych na sobie. Z kolei wartości otwartości i przekraczania siebie tworzą obszar wartości wzrostu, wartości wolnych od lęku, podczas gdy wartości umacniania siebie i zachowawczości tworzą wartości ochrony siebie, unikania lęku i zagrożenia ${ }^{17}$.

Specyfika funkcjonowania żon Anonimowych Alkoholików. Faktem jest, że kobiety te są współuzależnione, a ta konkretna forma uzależnienia przejawia się zależnością od drugiej osoby (męża alkoholika) i jej problemów ${ }^{18}$. Cechą charakterystyczną dla osoby współuzależnionej jest permanentna nadzieja i dążenie do odciągnięcia współmałżonka od picia oraz stosowanie przy tym usztywnionych i ograniczonych zachowań oraz reakcji. Niejednokrotnie przeżywane są przykre stany emocjonalne w czasie przyjmowania alkoholu przez małżonka (m.in. poczucie winy, niepokój, permanentne martwienie się, złudne nadzieje, zakłopotanie, zamęt, kłamstwa, rozczarowanie, złość, bezradność, letarg, rozpacz, poczucie krzywdy) i obniżenie ich intensywności podczas abstynencji partnera. Dodatkowym obciążeniem jest doświadczana niemożność rozstania się z osobą uzależnioną, mimo okresowych pragnień odejścia od niej, a także problemy seksualne.

Naszkicowane objawy koalkoholizmu wskazują, iż zjawisko to występuje zarówno w okresach picia małżonka, jak i w czasie podejmowanej przez niego abstynencji i prób leczenia. Wywiera on zatem istotne znaczenie dla przebiegu relacji między mężem a żoną, i między wszystkimi członkami rodziny ${ }^{19}$. Tym samym powrót do stanu równowagi wymaga nie tylko czasu, wysiłku i ogromnego zaangażowania kobiety współuzależnionej, ale również cierpliwości i wytrwałości ${ }^{20}$. W tym kontekście jawi się pytanie o preferencje wartości kobiet współuzależnionych: jakie wartości wiążą się z jakością i trwałością ich małżeństwa. Na związek jakości i trwałości małżeństwa z preferowanymi przez

17 J. Cieciuch, Pomiar wartości..., s. 26.

${ }_{18}$ L. Cierpiałkowska, Alkoholizm. Małżeństwa w procesie zdrowienia, Poznań 1997; L. Cierpiałkowska, M. Ziarko, Psychologia uzależnień - alkoholizm, Warszawa 2010; A. Margasiński, Analiza psychologiczna systemów rodzinnych z chorobą alkoholowa, Częstochowa 1996; J. Mellibruda, Psychologiczna analiza funkcjonowania alkoholików i członków ich rodzin. Podsumowanie badań realizowanych w latach 1986-1990. Studia psychologiczna nad funkcjonowaniem osób z problemami alkoholowymi i metodami terapii. T. 2, Warszawa 1999, s. 114-115; J. Mellibruda, H. Szczepańska, Psychologiczne problemy żon alkoholików, sprawozdanie z II fazy badań, Warszawa 1989; J. Mellibruda, H. Szczepańska, Wspótuzależnienie i inne problemy psychologiczne żon pacjentów uzależnionych, Warszawa 1989.

19 Tamże. Zob. też: H. Szczepańska, Żony alkoholików, Warszawa 1992.

20 Tamże. Zob. też: H. Kalkowski, Pod jednym dachem $z$ alkoholikiem, online: http://www.stowarzyszeniefidesetratio.pl/Presentations0/dach.pdf [dostęp: 1 marca 2020]. 
osobę wartościami zwraca uwagę wielu autorów między innymi Lewis i Spanier ${ }^{21}$, Rostowski $^{22}$, Ryśs ${ }^{23}$, Jankowiak ${ }^{24}$, Doniec ${ }^{25}$ czy Adamczyk ${ }^{26}$. Wymienieni twórcy zwracają uwagę, że preferowanie określonych wartości scala więź i relację małżeńską. Inklinowanie religii i wartości społecznych, dodatnio oddziaływuje na jakość wspólnoty małżeńskiej. Adamczyk ${ }^{27}$, Doniec ${ }^{28}$ i Ryśs ${ }^{29}$ przedstawiają typy wartości preferowanych przez małżonków, ważne z punktu widzenia jakości więzi. Należą do nich wartości rodzinne takie jak dbałość o partnera i wspólne gospodarstwo domowe, umiłowanie rodzicielstwa oraz gotowość do poświęcania się dla rodziny. Z kolei nadawanie wysokiej rangi wartościom egocentrycznym może wpływać negatywnie na jakość i trwałość związkuº

\section{Problem i hipotezy}

Biorąc pod uwage powyższe rozważania, jawi się problem badawczy, który można oddać w pytaniu: jakie powiązania istnieją między wartościami preferowanymi przez żony Anonimowych Alkoholików a jakością i trwałością ich związku małżeńskiego?

Teoretyczne analizy i badania pozwalają na wysunięcie następujących hipotez:

H.1.Wartości preferowane przez żony AA wiążą się z jakością ich związków małżeńskich.

H.1.1. Preferencja wartości nastawionych na przekraczanie „Ja” wiąże się z wyższą jakością związku małżeńskiego.

H.1.2. Preferencja wartości nastawionych na umacnianie „Ja” obniża jakość związku małżeńskiego.

${ }^{21}$ R.A. Lewis, G.B. Spanier, Theorizing about the Quality and Stability of Marriage... Zob. też: M. Ryś, Jakość i trwałość małżenstwa...; G.B. Spanier, Measuring Dyadic Adjustment...; G.B. Spanier, R.A. Lewis, Marital Quality...

${ }^{22}$ J. Rostowski, Zarys psychologii małżeństwa: psychologiczne uwarunkowania dobranego zwiazku matżeńskiego, Warszawa 1987.

${ }^{23}$ M. Ryś, Wplyw dzieciństwa na późniejsze życie w małżeństwie i rodzinie. Studium psychologiczne. Czesść II. Badanie empiryczne, Warszawa 1992; M. Ryś, Jakość i trwałość matżeństwa...; M. Ryś, Wspólny system wartości w małżeństwie, „Powiernik Rodzin” 1997, nr 11; M. Ryś, Psychologia małżeństwa w zarysie, Warszawa 1999.

${ }^{24}$ B. Jankowiak, Problematyka jakości i trwałości relacji partnerskich $w$ teorii i badaniach, „Przegląd Terapeutyczny" 2007, 3, s. 1-25.

${ }_{25}$ R. Doniec, Rodzina wielkiego miasta, Kraków 2001.

${ }^{26} \mathrm{~K}$. Adamczyk, Inteligencja emocjonalna i system wartości małżonków a ich komunikacja interpersonalna, „Kwartalnik Naukowy” 2013, 2(13), s. 72-101.

27 Tamże.

${ }^{28}$ R. Doniec, Rodzina wielkiego miasta...

${ }^{29}$ M. Ryś, Wplyw dziecinstwa...

${ }^{30}$ J. Laskowski, Trwałość wspólnoty małżeńskiej, Warszawa 1987. 
H.2.Wartości preferowane przez żony AA wiążą się z trwałością ich związków małżeńskich.

H.2.1. Preferencja wartości nastawionych na przekraczanie „Ja” wiąże się z wyższą trwałością związku małżeńskiego.

H.2.2. Preferencja wartości nastawionych na umacnianie „Ja” zmniejsza trwałość związku małżeńskiego.

\section{Metody}

Do badań wykorzystano baterię testów, obejmującą Portretowy Kwestionariusz Wartości S. Schwartza (PVQ-40), Skalę Jakości i Trwałości Małżństwa M. Ryś oraz arkusz biograficzny.

Arkusz biograficzny. Weryfikowano w nim podstawowe zmienne socjodemograficzne, m.in. wiek, wykształcenie, stan cywilny i miejsce zamieszkania.

Portretowy Kwestionariusz Wartości S. Schwartza (PVQ-40) ${ }^{31}$. Metoda służy do mierzenia preferencji 10 typów wartości, opisanych na polu koła ${ }^{32}$. Polska adaptacja przygotowana przez J. Cieciucha i Z. Zaleskiego ${ }^{33}$ zawiera 40 itemów. Poszczególne pozycje kwestionariusza opisują różnych ludzi w kategoriach ich aspiracji, celów i przekonań. Zadaniem osoby badanej jest udzielenie odpowiedzi na pytanie: W jakim stopniu ten ktoś jest podobny do Ciebie? Respondent ma do dyspozycji 6-stopniową skalę. Rzetelność szacowana na podstawie współczynnika alfa Cronbacha jest zadowalająca. Dotyczy to zarówno poszczególnych 10 typów wartości, jak i metakategorii. Trafność metody była testowana przy pomocy skalowania wielowymiarowego i konfirmacyjnej analizy czynnikowej. Bazując na zebranych danych, uznano ją za wysoką ${ }^{34}$. Wartość wskaźnika alfa Cronbacha w grupie adolescentów wynosi jednak zaledwie $0,48^{35}$.

W badaniach własnych, aby wyodrębnić czynniki składowe preferowanych wartości, wykonano eksploracyjną analizę czynnikową metodą głównych składowych z rotacją Varimax ${ }^{36}$. Wyszczególniono dwa czynniki, spójne z koncepcją

31 S.H. Schwartz, Universals in the content and structure of values...; S.H. Schwartz, Basic human values... Zob. też: P. Brzozowski, Uniwersalność struktury wartości...; J. Cieciuch, Kształtowanie się systemu wartości...; J. Cieciuch, Pomiar wartości...; S.H. Schwartz et al., Refining the theory...

32 Bardziej szczegółowy opis poszczególnych wartości oraz ich typologii został zaprezentowany w części teoretycznej, w paragrafie poświęconym systemowi wartości.

33 J. Cieciuch, Z. Zaleski, Polska adaptacja...

34 Tamże.

35 J. Cieciuch, Kształtowanie się systemu wartości....

$36 \mathrm{~W}$ opracowaniu tym analizy statystyczne wykonywano zgodnie z zaleceniami Schwartza i Cieciucha - na tzw. wynikach scentrowanych. Aby je wyznaczyć, obliczono średnią itemów właściwych dla konkretnej wartości, a następnie obliczono średni wskaźnik preferencji wszystkich itemów. Por. 
jednego $\mathrm{z}$ adaptatorów metody ${ }^{37}$. Pierwszy czynnik wyjaśniał 39\% wariancji wyników preferowanych wartości. W jego skład weszły pozycje dotyczące następujących typów wartości: osiągnięcia, stymulacja, kierowanie sobą, hedonizm i władza. Drugi czynnik wyjaśniał natomiast 33\% zmienności wyników preferowanych wartości i obejmował takie ich typy jak: uniwersalizm, bezpieczeństwo, przystosowanie, życzliwość i tradycja. Oba czynniki wyjaśniły łącznie $72 \%$ wariancji wyników wyjściowej zmiennej. Analizując uzyskane czynniki pod kątem psychologicznym, można stwierdzić, iż czynnik pierwszy określa preferowanie wartości skoncentrowanych na sobie; drugi zaś - skoncentrowanych na innych. Składowe wyróżnione w badaniach własnych są zatem zbliżone do modelu Cieciucha $^{38}$. W badanej grupie wskaźniki alfa Cronbacha wahają się natomiast w granicach 0,47 (tradycja) - 0,91 (hedonizm). Jeśli zaś chodzi o wyodrębnione czynniki, rzetelność preferowania wartości skoncentrowanych na sobie szacowana na podstawie współczynnika alfa Cronbacha wyniosła 0,796, natomiast rzetelność preferowania wartości skoncentrowanych na innych - 0,766.

Skala Jakości i Trwałości Małżeństwa autorstwa M. Ryśs ${ }^{39}$ bazuje na analizach wykonanych przez R.A. Lewisa i G.B. Spaniera ${ }^{40}$. Zebrane przez nich zmienne podzielono na dwie grupy - czynniki związane z jakością małżeństwa i jego trwałością. Skala dotycząca jakości relacji zawiera 40 pozycji, zaś skala traktująca o jej trwałości - 20 stwierdzeń. Respondenci korzystają z 5-stopniowej skali wskazując, w jakim stopniu dane stwierdzenie dotyczy ich małżeństwa. Liczba punktów w Skali Jakości Małżeństwa plasuje się w przedziale 40-200 punktów; natomiast w Skali Trwałości Małżeństwa - w zakresie 20-100 punktów. Wyniki te zmieniono na tetrony (2-10), co oznacza, że wartość graniczna to 6 . Tetrony 8-10 świadczą o bardzo wysokich wynikach, natomiast 2-4 - bardzo niskich. Trafność Skali testowano przez zastosowanie kryterium zewnętrznego - zbadano łącznie 60 małżeństw, które samodzielnie określiły swoją relację jako bardzo udaną lub bardzo nieudaną (po 30 par w każdej grupie) ${ }^{41}$.

W badaniach własnych przeprowadzono dodatkowo eksploracyjną analizę czynnikową metodą głównych składowych z rotacją Oblimin. Zabieg ten umożliwił wyszczególnienie czynników składowych trwałości małżeństwa. Czynnik pierwszy wyjaśniał $29 \%$ wariancji ogólnego wyniku trwałości małżeństwa. Nazwano go Przekonanie o trwałości małżeństwa. Czynnik drugi - 14\%

S.H. Schwartz, Basic human values...; J. Cieciuch, Kształtowanie się systemu wartości...; J. Cieciuch, Pomiar wartości....

37 J. Cieciuch, Pomiar wartości..., s. 26.

${ }^{38}$ Tamże; J. Cieciuch, Kształtowanie się systemu wartości... Zob. też: J. Cieciuch, Z. Zaleski, Polska adaptacja....

${ }^{39}$ M. Ryś, Jakość i trwałość małżeństwa....

${ }^{40}$ R.A. Lewis, G.B. Spanier, Theorizing about the Quality and Stability of Marriage....

${ }^{41}$ M. Ryś, Jakość i trwałość małżeństwa.... 
zmienności wyników tej zmiennej; nadano mu nazwę Umiejętność znoszenia napięć. Natomiast czynnik trzeci - 10\% wariancji wyników powyższej zmiennej. Określał on Niska atrakcyjność własnego małżeństwa. Powyższe trzy czynniki wyjaśniały łącznie 53\% wariancji wyników wyjściowej zmiennej. Rzetelność całej Skali Trwałości Małżeństwa oraz jej poszczególnych czynników okazała się nadal zadowalająca - współczynniki alfa Cronbacha wynoszą 0,71-0,87 dla poszczególnych czynników oraz 0,84 dla wyniku ogólnego. Współczynnik ten, dla Skali Jakości Małżeństwa, w badanej grupie wyniósł 0,95.

\section{Badane osoby i sposób przeprowadzania badań}

Przebadano 286 kobiet, których mężami są osoby uzależnione od alkoholu, uczęszczające na mityngi grupy AA. Badania obejmowały swym zakresem teren całego kraju. Miasta, w których były przeprowadzane, to wybrane miasta wojewódzkie oraz mniejsze miasta powiatowe i gminne. Projekt był realizowany głównie w związku z mityngami okolicznościowymi - rocznicowymi, będącymi jednocześnie mityngami otwartymi dla osób nieuzależnionych od alkoholu. Ankietowane samodzielnie wypełniały arkusze testowe; odbywało się to indywidualnie lub grupowo - przed częścią integracyjną mityngu.

$97,2 \%$ respondentek pozostaje w stałym związku małżeńskim, 2,8\% znajduje się w separacji. Średnia wieku badanych kobiet wyniosła $M=46,40$ lat; $S D=11,18$ lat. Większość kobiet ma wykształcenie wyższe (licencjat: 30,1\%; tytuł magistra: $25,5 \%)$. Około $18 \%$ badanych osób ukończyło edukację z wykształceniem średnim. Podobny odsetek $(16,4 \%)$ uzyskał wykształcenie zawodowe. 1,7\% posiada wykształcenie podstawowe lub podyplomowe (8\%). Najczęściej są to mieszkanki średnich miast (34,6\%). Nieco mniej osób pochodzi z małego (26,6\%) lub dużego miasta (23,1\%). Najmniejszy odsetek badanych mieszka na wsi $(15,7 \%)$.

Jedną z istotnych zmiennych kontrolowanych w badaniach była także skłonność do konformizmu społecznego. Podejrzewano, że w tak specyficznej grupie (żony AA) zmienna ta może mieć kluczowe znaczenie. Okazało się jednak, że wyniki respondentek w Skali Kłamstwa EPQ-R (S) ułożyły się w rozkład normalny: $W(286)=0,950 ; p=0,001$. Oznacza to, że nasilenie tej zmiennej występuje w zbliżony sposób w populacji, co w grupie badanej.

\section{Wyniki}

Rezultaty testowania postawionych wcześniej hipotez zawierają poniższe tabele. Przedstawiają one powiązania pomiędzy systemem wartości żon Anonimowych Alkoholików a jakością (tab. 1) i trwałością (tab. 2) ich małżeństw. 


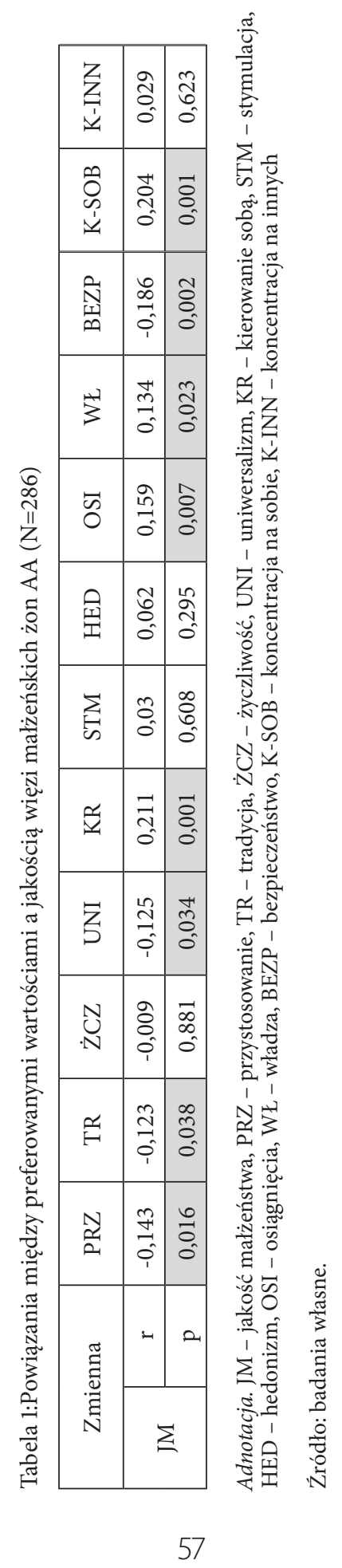




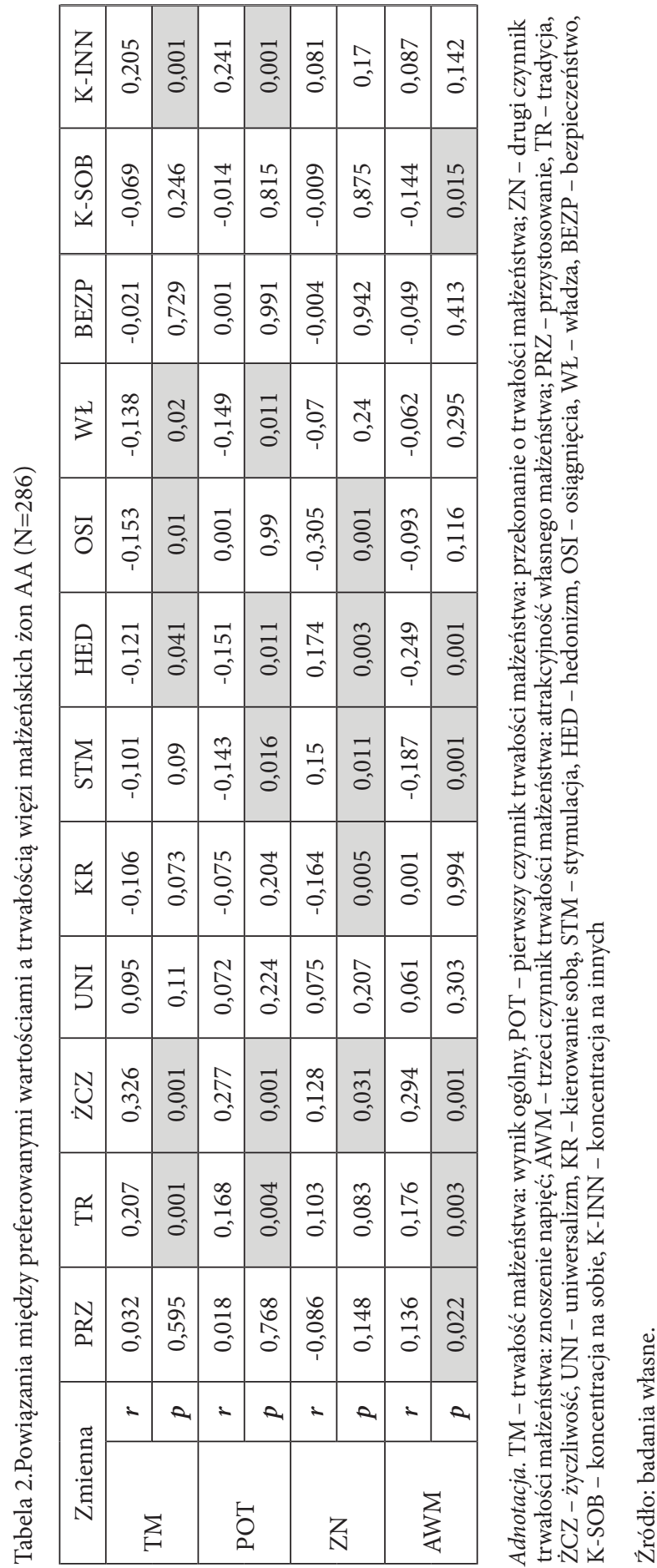


Korelacje istotne statystycznie odnotowano pomiędzy większością preferowanych typów wartości a jakością (tab. 1) i trwałością związku małżeńskiego oraz z jej czynnikami (tab. 2). Najwięcej powiązań (po cztery, na pięć możliwych) wystąpiło z tradycją, życzliwością i hedonizmem. Najmniej zaś z uniwersalizmem i bezpieczeństwem (pojedyncze związki). Niektóre powiązania istotne statystycznie są dodatnie, inne ujemne. Ich siła jest bardzo niska lub niska.

Dane te można rozumieć następująco: żony Anonimowych Alkoholików, które za ważne uznają wartości takie jak przystosowanie, tradycja, uniwersalizm i bezpieczeństwo, mogą żyć w niesatysfakcjonujących małżeństwach. Natomiast kobiety preferujące władzę i osiągnięcia, które lubią sobą kierować, mogą mieć bardziej udane relacje małżeńskie (tab. 1). Wyższa trwałość związku współwystępuje z cenieniem tradycji i życzliwości przy niższym zainteresowaniu hedonizmem oraz pragnieniem osiągnięć i władzy. Osoby, dla których ważna jest tradycja i życzliwość, oraz stroniące od stymulacji, hedonizmu i władzy, mogą cechować się silnym przekonaniem o trwałości zawartego małżeństwa aż do śmierci jednej ze stron. Respondentki potrafiące znosić różnego rodzaju napięcia i trudności wynikające z życia rodzinnego mogą wybierać takie wartości jak życzliwość, stymulacja czy hedonizm, a unikać kierowania sobą czy znaczących sukcesów. Wreszcie im niżej kobieta ocenia atrakcyjność swojego związku małżeńskiego, czyli chce zaangażować się w nowy, pozamałżeński związek, potrzebuje częstego przebywania poza domem, ma stałe poczucie, że inni mężczyźni są bardziej atrakcyjni niż współmałżonek, tym bardziej preferuje ona przystosowanie, tradycję i życzliwość, przy jednoczesnym odrzuceniu stymulacji i hedonizmu (tab. 2).

Powiązania istotne statystycznie zarejestrowano również pomiędzy czynnikami preferowanych wartości, wyodrębnionymi w analizie czynnikowej - koncentracją na sobie vs koncentracją na innych - a jakością (tab. 1) i trwałością małżeństwa (tab. 2). Okazało się, że cenienie wartości skoncentrowanych na sobie współwystępuje z jakością relacji (związek był niski, dodatni) oraz z niską oceną jej atrakcyjności (związek również niski, ale ujemny). Można więc powiedzieć, że wraz z wybieraniem wartości skoncentrowanych na sobie (takich jak kierowanie sobą, stymulacja, hedonizm, osiągnięcia czy władza), poprawia się jakość małżeństwa, a obniża ocena jego atrakcyjności ${ }^{42}$. Preferowanie przystosowania, tradycji, życzliwości, uniwersalizmu czy bezpieczeństwa (czyli wartości skoncentrowanych na innych) wiąże się z kolei ze wzrostem ogólnego wyniku trwałości małżeństwa i przekonania o trwałości więzi.

${ }^{42}$ Należy zauważyć, że wysoki wynik w skali atrakcyjność własnego małżeństwa oznacza, że respondentka ocenia swój związek negatywnie, gdyż uzyskane wyniki w tej skali interpretuje się odwrotnie (skala jest odwrócona). 


\section{Podsumowanie i dyskusja wyników}

Pierwsza część analiz dotyczyła testowania powiązań pomiędzy jakością więzi matżeńskiej a preferencją 10 typów wartości. Powiązania istotne statystycznie odnotowano między siedmioma wartościami: przystosowaniem, tradycją, uniwersalizmem, kierowaniem sobą, osiągnięciami, władzą i bezpieczeństwem. Uzyskane wyniki dowiodły, że kobiety wybierające wartości takie jak przystosowanie, tradycję, uniwersalizm i bezpieczeństwo, mogą doświadczać mniejszej satysfakcji z własnego małżeństwach. Znaczenie ograniczania swych impulsów, dążeń, działań, aby nie krzywdzić i nie denerwować innych oraz by nie naruszać norm i oczekiwań społecznych, może wiązać się z niższym poziomem wzajemnego zaakceptowania, tolerancji, szacunku, życzliwości, szczęścia, miłości czy okazywania uczuć. Również mniej satysfakcjonujące może być pożycie seksualne tych kobiet. Preferowanie akceptacji, podtrzymywania i respektu wobec tradycji i zwyczajów własnej rodziny oraz idei religijnych lub kulturowych może współwystępować z niskim zadowoleniem z udziału współmałżonka w pracach domowych i jego pracy zawodowej. Niskie może być także podobieństwo małżonków pod względem charakteru, przekonań i praktyk religijnych, postaw rodzicielskich, ważnych poglądów, wartości czy norm moralnych. Pragnienie zrozumienia, szacunku i tolerancji może wiązać się także z niższym zaufaniem do współmałżonka, brakiem poczucia bycia zrozumianym we wszystkich ważnych sytuacjach, mniejszą otwartością, wiernością, uczciwością czy szczerością, których niewątpliwie często doświadczają osoby żyjące z partnerem zmagającym się z chorobą alkoholową. Osoby badane mogą nie akceptować zainteresowań małżonka i nie mieć z nim wspólnych tematów do rozmów. Mogą nie czuć wpływu na ubogacenie wewnętrzne partnera oraz nie wierzyć, że wzajemna miłość będzie się rozwijała. Podobnie zwracanie szczególnej uwagi na bezpieczeństwo, harmonię, porządek i stabilizację, zarówno w relacjach międzyludzkich, jak i całym społeczeństwie, może dobitniej uświadamiać odczuwany niedosyt bliskości, jedności i więzi z mężem. Kobiety mogą czasem tracić świadomość partnerstwa w małżeństwie i zastanawiać się, czy małżonek jest właściwie wybranym partnerem życiowym. Trudności w rozwiązywaniu konfliktów i stała ich obecność, przeciętne poczucie atrakcyjności męża, niewielka wiedza o małżeństwie przed jego zawarciem, nieznajomość płodności małżeńskiej i niezgodność posiadanej liczby dzieci z oczekiwaniami - to wszystko sprawia, że zadowolenie kobiet i ich satysfakcja z małżeństwa może być niska, zwłaszcza u osób preferujących bezpieczeństwo własne czy swojej rodziny. $Z$ kolei relacje tych żon AA, które lubią sobą kierować, dla których ogromne znaczenie ma władza i osiągnięcia, mogą być dla nich bardziej zadowalające. Żony Anonimowych Alkoholików ceniące niezależność i samodzielność w myśleniu, działaniu i wyborach, dla których wolność, twórczość i kreatywność są ważne, mogą wyżej oceniać 
przystosowanie swoich wspólnot małżeńskich, w których są "głowami rodziny”. Im bardziej znacząca jest dla nich dominacja nad innymi oraz kontrolowanie ich i zasobów, tym wyżej oceniają zintegrowanie swych związków, w których permanentnie kontrolują picie uzależnionego męża. Wreszcie im ważniejsze są dla nich osobiste sukcesy, zdobyte dzięki własnym kompetencjom, tym mogą oceniać swe więzi jako bardziej satysfakcjonujące, w których funkcjonują mimo przytłaczających je spraw i trudności. Analogiczne powiązania widoczne były także między preferowaniem wartości skoncentrowanych na sobie a jakością małżeństw: wraz z cenieniem osiągnięć, władzy i kierowania sobą, rośnie jakość relacji. Konkludując powyższe interpretacje, można stwierdzić, że hipoteza mówiąca, iż wartości preferowane przez żony AA wiążą się z jakością ich związków małżeńskich (H.1.), została potwierdzona, za wyjątkiem preferowania stymulacji. Z kolei hipoteza stwierdzająca współwystępowanie preferowania wartości nastawionych na przekraczanie „Ja” (czyli życzliwości i uniwersalizmu) z wyższą jakością związku małżeńskiego żon AA (H.1.1.) została potwierdzona częściowo. Powiązania wystąpiły bowiem między jakością relacji małżeńskiej a preferowaniem uniwersalizmu. Druga hipoteza szczegółowa, upatrująca powiązania między preferowaniem wartości nastawionych na umacnianie "Ja" (czyli osiągnięć, władzy i hedonizmu) z niższą jakością związku małżeńskiego (H.1.2.), została natomiast potwierdzona w całości.

Wyniki badań własnych można odnieść do samej teorii jakości i trwałości małżeństwa autorstwa Lewisa i Spaniera ${ }^{43}$. Autorzy ci wskazują bowiem na system wartości małżonków jako jeden z czynników oddziałujących na relację małżeńską, na jej jakość i trwałość. Uzyskane wyniki wpisują się także w prace tych psychologów, którzy podkreślają znaczenie systemu wartości i spójności tego systemu w jakości i trwałości małżeństwa. Tezy takie stawiają Rostowski ${ }^{44}$, Ryśs $^{45}$, Jankowiak ${ }^{46}$, Doniec ${ }^{47}$ czy Jabłońska ${ }^{48}$. Uzyskane w niniejszych badaniach wyniki znajdują również pewne odzwierciedlenie w wynikach Brudki i Ciuły ${ }^{49}$, dotyczących osób w późnej dorosłości. W prezentowanych badaniach odnotowano korelacje istotne statystycznie między jakością wspólnoty małżeńskiej i tradycją. Brudek i Ciuła, stwierdzili dodatnie związki pomiędzy ogólnym poczuciem satysfakcji z małżeństwa oraz wartościami moralnymi, świętymi

${ }^{43}$ R.A. Lewis, G.B. Spanier, Theorizing about the Quality and Stability of Marriage... Zob. też: G.B. Spanier, R.A. Lewis, Marital Quality...

${ }_{44}$ J. Rostowski, Zarys psychologii małżeństwa...

${ }^{45}$ M. Ryś, Wplyw dzieciństwa...; M. Ryś, Jakość i trwałość małżeństwa..., M. Ryś, Wspólny system wartości...; M. Ryś, Psychologia małżeństwa w zarysie...

${ }^{46}$ B. Jankowiak, Problematyka jakości i trwałości relacji partnerskich...

47 R. Doniec, Rodzina wielkiego miasta...

${ }^{48}$ A. Jabłońska, Czy będziemy ze sobą szczęśliwi...

${ }^{49}$ P. Brudek, G. Ciuła, Hierarchia wartości a satysfakcja ze związku małżeńskiego u osób w okresie późnej dorosłości, „Śląskie Studia Historyczno-Teologiczne” 2013, nr 2, s. 371-386. 
i świętościami świeckimi ${ }^{50}$. Zgadza się to $\mathrm{z}$ definicją wartości tradycyjnych w ujęciu Cieciucha ${ }^{51}$ - akceptacja, podtrzymywanie i respekt w stosunku do idei, zwyczajów i tradycji religii, kultury czy własnej rodziny. Przytoczone wyniki należy jednak ostrożnie odnosić do uzyskanych tu rezultatów, głównie ze względu na różną specyfikę osób badanych w obu projektach: żony AA oraz osoby starsze. Bazując na psychologii life-span, rozwój ontogenetyczny człowieka realizuje się na każdym etapie jego życia ${ }^{52}$. Specyfika zmian rozwojowych, jakie pojawiają się w okresie późnej dorosłości, dotyczy z jednej strony wyższego poziomu określonych funkcji psychicznych, $\mathrm{z}$ drugiej zaś - procesów regresyjnych (zwłaszcza $\mathrm{w}$ sferze fizycznej i poznawczej) ${ }^{53}$. Mowa tutaj zarówno o całej grupie zaburzeń specyficznych dla tego okresu życia, jak również o pewnych znamiennych cechach określanych jako psychika starcza ${ }^{54}$. W takim ujęciu starość powinna być postrzegana jako czas wielopłaszczyznowych zmian, również w zakresie systemu wartości i relacji międzyludzkich ${ }^{55}$. $Z$ drugiej zaś strony, nie można też zapominać o specyfice funkcjonowania żon Anonimowych Alkoholików, co zostało szerzej opisane w części teoretycznej opracowania.

Druga część analiz dotyczyła testowania powiązań pomiędzy trwałością więzi matżeńskiej a preferencją 10 typów wartości. Związki zarejestrowano z pięcioma wartościami: tradycją i życzliwością (korelacje dodatnie) oraz hedonizmem, osiągnięciami i władzą (korelacje ujemne). Uzyskane wyniki unaoczniły, że kobiety akceptujące, podtrzymujące i respektujące tradycje, zwyczaje i idee własnej rodziny, religii lub kultury mogą mieć bardziej trwałe małżeństwa. Mogą one także wysoko cenić dbałość o dobro najbliższych: rodziny lub przyjaciół. Z kolei żony AA koncentrujące się na przyjemności i zmysłowym zaspokojeniu, ukierunkowane na status i prestiż społeczny, dominację i kontrolowanie innych oraz osiąganie własnych sukcesów, mogą mieć mniej trwałe relacje. Osoby stroniące od stymulacji, które nie potrzebują niespodzianek czy zajmo-

50 Tamże.

51 J. Cieciuch, Kształtowanie się systemu wartości...; J. Cieciuch, Pomiar wartości... Zob. też: J. Cieciuch, Z. Zaleski, Polska adaptacja...

52 P. Brudek, G. Ciuła, Hierarchia wartości... Zob. też: P.B. Baltes, W.H. Reese, L.P. Lipsitt, Life-span developmental psychology. „Annual Review of Psychology” 1980, nr 1, s. 65-110.

53 P. Brudek, G. Ciuła, Hierarchia wartości... Zob. też: M. Lövdén, P. Ghisletta, U. Lindenberger, Cognition in the Berlin Aging Study (BASE): The First 10 Years, „Aging Neuropsychology and Cognition” 2004, nr 2-3, s. 104-133; M. Marsiske, J. Delius, I. Maas, U. Lindenberger, H. Scherer, C. Tesch-Römer, Sensory systems in old age, w: The Berlin Aging Study: Aging from 70 to 100, red. P.B. Baltes, K.U. Mayer, New York 1999, s. 360-383; P. Oleś, Psychologia człowieka dorosłego, Warszawa 2012.

54 P. Brudek, G. Ciuła, Hierarchia wartości... Zob. też: A. Bilikiewicz, T. Parnowski, Starzenie się i zaburzenia psychiczne wieku podeszłego, w: Psychiatria. Podręcznik dla studentów medycyny, red. A. Bilikiewicz, Warszawa 2011, s. 457-502.

55 P. Brudek, G. Ciuła, Hierarchia wartości... Zob. też: M. Straś-Romanowska, Późna dorosłość, w: Psychologia rozwoju człowieka, T. 2., red. B. Harwas-Napierała, J. Trempała, Warszawa 2011, s. $263-289$. 
wania się różnymi, nowymi rzeczami, które niechętnie podejmują ryzyko i nie poszukają przygód, mogą odznaczać się wyższym przekonaniem, że małżeństwo będzie trwałe. Kobiety te rzadko mogą szukać także sposobności, by się zabawić - przyjemność i korzystanie z życia oraz dobra zabawa nie są dla nich najważniejsze. Analogicznie sprawa wygląda z pragnieniem władzy: bogactwo, posiadanie dużej ilości pieniędzy i drogich rzeczy może być przez nie oceniane jako mniej znaczące (zwłaszcza w obliczu trudności zdrowotnych pijącego męża). Kobiety silnie przekonane o trwałości własnego małżeństwa mogą nie lubić odgrywanej przez siebie roli lidera (grupy - rodziny czy konkretnej sytuacji), który ciągle mówi innym, co mają robić i jak się zachowywać. Respondentki charakteryzujące się wyższym przekonaniem, że zawarte małżeństwo będzie trwało aż do śmierci, preferują życzliwość i wartości tradycyjne. Mogą one sądzić, że trzeba się cieszyć $\mathrm{z}$ tego, co się obecnie ma. Istotna może być dla nich religijność, podtrzymywanie zasad i zwyczajów przyswojonych z domu rodzinnego oraz bycie pokornym, skromnym człowiekiem, który nie zwraca na siebie uwagi. Kluczowe może być dla nich także pomaganie innym oraz oddanie i lojalność wobec nich, a także umiejętność przebaczenia. Respondentki, często i stosunkowo dobrze znoszące różnego rodzaju napięcia i trudności wynikające z życia rodzinnego, mogą cechować się większą życzliwością, niechęcią do kierowania sobą i mniejszą potrzebą wysokich osiągnięć. Cenne może być dla nich dbanie o dobro najbliższych. Natomiast bycie niezależnym, wolnym i twórczym, osiągającym coraz to nowe sukcesy - może okazać się mniej wartościowe. Zamiast tego mogą one preferować takie wartości jak stymulacja czy hedonizm, które mogą być przez nie stosowane jako ucieczkowe strategie radzenia sobie z problemami. Można wywnioskować, że raczej zajmują się różnymi, nowymi rzeczami oraz chętnie podejmują ryzyko, co może wynikać z przejmowania części obowiązków dysfunkcjonalnego partnera. Kobiety te mogą także lubić przyjemności, dobrą zabawę i korzystanie z życia jako swego rodzaju odskocznię od trudów codzienności. Wreszcie niechęć do angażowania się w nowy, pozamałżeński związek emocjonalny, brak stałego poczucia, że inni mężczyźni są bardziej atrakcyjni niż współmałżonek czy brak potrzeby częstego przebywania poza domem współwystępują z preferowaniem przez osoby badane przystosowania, tradycji i życzliwości oraz odsuwaniem przez nie na bok stymulacji i hedonizmu. Kobiety te mogą starać się przestrzegać zasad i norm wyniesionych z domów rodzinnych, nawet jak nikt nie widzi tego, co robią. Ważne może być dla nich odpowiednie i stosowne zachowanie, bycie skromnym człowiekiem, który nie zwraca na siebie uwagi. Istotne może być również pomaganie innym, lojalność wobec nich i umiejętność przebaczenia. Kobiety, które niżej oceniają atrakcyjność własnego małżeństwa (wymiar trwałości małżeństwa), mogą nie lubić niespodzianek. Raczej niechętnie będą zajmować się nowymi rzeczami. Tylko z konieczności lub pod przymusem 
będą podejmować ryzyko. Nie będą też szukały przygód ani sposobności (np. w alternatywnym związku pozamałżeńskim). Przyjemność i korzystanie z życia raczej nie są dla nich jednymi z najważniejszych wartości. Odnotowano także trzy powiązania między trwałością małżeństwa (i jego trzema składowymi) a dwoma czynnikami preferowania wartości. Zauważono, że trwałość relacji małżeńskiej współwystępuje $\mathrm{z}$ wybieraniem wartości skoncentrowanych na innych. Analogiczne związki zaobserwowano z przekonaniem o trwałości więzi małżeńskiej. Można więc powiedzieć, że cenienie przystosowania, tradycji, życzliwości, uniwersalizmu czy bezpieczeństwa - czyli wartości skoncentrowanych na innych - współwystępuje ze wzrostem trwałości małżeństwa i jej składowej, jaką jest przekonanie o trwałości wspólnoty. Trzecie powiązanie zarejestrowano między niską atrakcyjnością własnego małżeństwa a preferowaniem wartości skoncentrowanych na sobie. To z kolei oznacza, że wraz z preferowaniem wartości skoncentrowanych na sobie (takich jak kierowanie sobą, stymulacja, hedonizm, osiągnięcia czy władza), ocena własnego związku małżeńskiego jest mniej negatywna. Konkludując powyższe interpretacje, można stwierdzić, że hipoteza mówiąca, iż wartości preferowane przez żony AA wiążą się z trwałością ich związków małżeńskich (H.2.), została potwierdzona, za wyjątkiem wartości stymulacji. Z kolei hipoteza stwierdzająca współwystępowanie preferowania wartości nastawionych na przekraczanie „Ja” (czyli życzliwości i uniwersalizmu) $\mathrm{z}$ wyższą trwałością związku małżeńskiego żon AA (H.2.1.) została potwierdzona częściowo. Powiązania wystąpiły bowiem między trwałością relacji małżeńskiej a preferowaniem życzliwości. Druga hipoteza szczegółowa, upatrująca powiązania między preferowaniem wartości nastawionych na umacnianie „Ja" (czyli osiągnięć, władzy i hedonizmu) z niższą trwałością związku małżeńskiego (H.2.2.), została natomiast potwierdzona w całości.

Weryfikacja hipotezy H.2. wpisuje się w koncepcję jakości i trwałości małżeństwa Lewisa i Spaniera ${ }^{56}$. Wskazywali oni na system wartości małżonków jako czynnik konstruujący stabilność ich wspólnoty. Także Brudek i Ciuła ${ }^{57}$ odnotowali dodatnie związki między ogólnym poczuciem satysfakcji z małżeństwa oraz wartościami moralnymi, świętymi i świętościami świeckimi, oraz ujemne korelacje pomiędzy satysfakcją z małżeństwa a wartościami hedonistycznymi oraz sprawnością i siłą fizyczną. Wyniki naszych badań pokazały natomiast, iż czwarta zmienna - wartości hedonistyczne - okazały się ujemnie skorelowane $\mathrm{z}$ trwałością relacji małżeńskiej, co było zbieżne z doniesieniami wspomnianych badaczy ${ }^{58}$.

56 R.A. Lewis, G.B. Spanier, Theorizing about the Quality and Stability of Marriage... Zob. też: G.B. Spanier, R.A. Lewis, Marital Quality...

57 P. Brudek, G. Ciuła, Hierarchia wartości...

58 Tamże. 
Myśląc o wnioskach aplikacyjnych z niniejszych badań, można wysunąć sugestię mającą na celu wspieranie kobiet w koncentracji na sobie i własnych potrzebach, poprzez rozwijanie u nich preferowania takich wartości jak osiągnięcia, stymulacja, kierowanie sobą, a także kształtowanie prawidłowego poczucia własnej wartości i troski o właściwe zaspokojenie potrzeb czy relacje $\mathrm{z}$ innymi ludźmi budowane na zasadzie partnerstwa (a nie podporządkowania się czy władzy). Dzięki temu możliwa będzie poprawa jakości funkcjonowania ich związków małżeńskich. Można także afirmować koncentrację kobiet na innych ludziach, czyli wybieranie przez nie uniwersalizmu, bezpieczeństwa, przystosowania, życzliwości czy tradycji. Dzięki temu możliwe będzie pogłębianie trwałości więzi małżeńskiej.

Podając szereg możliwości dla przyszłych badań, zaleca się eksplorację niniejszego tematu w odniesieniu do mężów uzależnionych od alkoholu, uczestników grup AA. Ciekawe mogłyby okazać się również analizy osób uzależnionych, ale korzystających z innych niż grupa AA form pomocy. Bieżące kwestie można odnieść też do osób uzależnionych od innych substancji psychoaktywnych lub innych form uzależnień, takich jak chociażby hazard. Możliwe, że interesujące okazałyby się badania z udziałem osób żyjących w związkach niesakramentalnych - proponuje się zatem wykonanie analiz z uwzględnieniem osób w tzw. „wolnych związkach”, w separacji czy po rozwodzie.

\section{Bibliografia}

Adamczyk K., Inteligencja emocjonalna i system wartości małżonków a ich komunikacja interpersonalna, „Kwartalnik Naukowy" 2013, nr 2, s. 72-101.

Baltes P.B., Reese W.H., Lipsitt L.P., Life-span developmental psychology. „Annual Review of Psychology" 1980, nr 1, s. 65-110.

Bilikiewicz A., Parnowski T., Starzenie się i zaburzenia psychiczne wieku podeszłego, w: Psychiatria. Podręcznik dla studentów medycyny, red. A. Bilikiewicz, Warszawa 2011, s. 457-502.

Brudek P., Ciuła G., Hierarchia wartości a satysfakcja ze zwiq̨zku małżeńskiego u osób w okresie późnej dorosłości, „Śląskie Studia Historyczno-Teologiczne” 2013, nr 2, s. 371-386.

Brzozowski P., Uniwersalność struktury wartości: Koncepcja Shaloma H. Schwartza, „Roczniki Psychologiczne" 2002, nr 5, s. 27-51.

Chybicka A., Karasiewicz K., Zadowolenie z intymnych relacji oraz poczucie własnej atrakcyjności i komunikacji w zwiq̨zkach narzeczeńskich i małżeńskich, w: Psychologia Rodziny. Małżeństwo i rodzina wobec współczesnych wyzwań, red. T. Rostowska, Warszawa 2009, s. 136-161.

Cieciuch J., Kształtowanie się systemu wartości od dzieciństwa do wczesnej dorosłości, Warszawa 2013.

Cieciuch J., Pomiar wartości w zmodyfikowanym modelu Shaloma Schwartza, "Psychologia Społeczna" 2013, 8, 1(24), s. 22-41.

Cieciuch J., Zaleski Z., Polska adaptacja Portretowego Kwestionariusza Wartości Shaloma Schwartza, "Czasopismo Psychologiczne" 2011, nr 2, s. 251-262.

Cierpiałkowska L., Alkoholizm. Małżeństwa w procesie zdrowienia, Poznań 1997.

Cierpiałkowska L., Ziarko M., Psychologia uzależnień - alkoholizm, Warszawa 2010.

Doniec R., Rodzina wielkiego miasta, Kraków 2001. 
Dudziak U., Seksualność - jako szczególny sposób i możliwość wyrażania miłości, w: Miłość i życie. Małżeństwo i rodzina w budowaniu cywilizacji miłości, red. M. Ryś, Z. Struzik, Warszawa 2015, s. 67-72.

Jabłońska A., Czy będziemy ze sobą szczęśliwi - czyli cała rzecz o satysfakcji ze zwiq̨zku, online: http:// www.psychologia-spoleczna.pl/artykuly/864-czy-bdziemy-ze-sob-szczliwi-czyli-caa-rzecz-o-satysfakcji-ze-zwizku.html [dostęp: 1 marca 2020].

Jankowiak B., Problematyka jakości i trwałości relacji partnerskich w teorii i badaniach, „Przegląd Terapeutyczny" 2007, nr 3, s. 1-25.

Kalkowski H., Pod jednym dachem z alkoholikiem, online: http://www.stowarzyszeniefidesetratio. pl/Presentations0/dach.pdf [dostęp: 1 marca 2020].

Laskowski J., Trwałość wspólnoty małżeńskiej, Warszawa 1987.

Lewis R.A., Spanier G.B., Theorizing about the Quality and Stability of Marriage, w: Contemporary Theories about the Family. Research-Based Theories. Vol. 1, red. W.R. Burr, R. Hill, F.I. Nye, I.L. Reiss, New York 1979, s. 268-294.

Margasiński A., Analiza psychologiczna systemów rodzinnych z chorobq alkoholowa, Częstochowa 1996.

Matusewicz Cz., Psychologia wartości, Warszawa; Poznań 1975.

Mellibruda J., Psychologiczna analiza funkcjonowania alkoholików i członków ich rodzin. Podsumowanie badań realizowanych w latach 1986-1990. Studia psychologiczna nad funkcjonowaniem osób z problemami alkoholowymi i metodami terapii. T. 2, Warszawa 1999.

Mellibruda J., Szczepańska H., Psychologiczne problemy żon alkoholików, sprawozdanie z II fazy badań, Warszawa 1989.

Mellibruda J., Szczepańska H., Współuzależnienie i inne problemy psychologiczne żon pacjentów uzależnionych, Warszawa 1989.

Oleś P., Psychologia człowieka dorosłego, Warszawa 2012.

Peplińska A., Psychologiczne i zdrowotne konsekwencje równoważenia ról zawodowych i rodzinnych, w: Zawodowe i zdrowotne problemy człowieka w różnych okresach dorosłości. Perspektywa psychologiczna, red. T. Rostowska, W. Budziński, Toruń 2012, s. 64-85.

Reber A., Reber E.S., Słownik psychologii, Warszawa 2001.

Rostowska T., Dojrzałość osobowa jako podstawowe uwarunkowanie życia małżeńskiego i rodzinnego, w: Psychologia w służbie rodziny, red. I. Janicka, T. Rostowska, Warszawa 2003, s. 45-55.

Rostowska T., Rozwojowe aspekty jakości życia rodzinnego, w: Jakość życia rodzinnego. Wybrane zagadnienia, red. T. Rostowska, Łódź 2006, s. 11-27.

Rostowska T., Aktywność zawodowa małżonków a jakość ich życia, w: Psychologia Rodziny. Małżeństwo i rodzina wobec współczesnych wyzwań, red. T. Rostowska, Warszawa 2009, s. 60-80.

Rostowska T., Miłość małżeńska w perspektywie psychologicznej, w: Małżeństwo i miłość. Kontekst psychologiczny i neuropsychologiczny, red. J. Rostowski, T. Rostowska, Warszawa 2014, s. 289-335.

Rostowska T., Rostowski J., Miłość jako wyznacznikjakości małżeńskiej, w: Rodzina - rozwój- praca. Wybrane zagadnienia, red. T. Rostowska, J. Rostowski, Łódź 2002, s. 9-21.

Rostowska T., Żylińska P., Stopień zaangażowania religijnego a poziom jakości małżeńskiej u partnerów, w: Psychologia Rodziny. Małżeństwo i rodzina wobec współczesnych wyzwań, red. T. Rostowska, Warszawa 2009, s. 117-135.

Rostowski J., Zarys psychologii małżeństwa: psychologiczne uwarunkowania dobranego zwiqzzu małżeńskiego, Warszawa 1987.

Rostowski J., Podobieństwo w zakresie sześciowymiarowego modelu dobranego zwiq̨zku małżeńskiego w ujęciu J. Rostowskiego (KDM-1), w: Małżeństwo i miłość. Kontekst psychologiczny i neuropsychologiczny, red. J. Rostowski, T. Rostowska, Warszawa 2014, s. 88-152.

Rostowski J., Rostowska T., Poziom zdrowia i dobrego samopoczucia jako następstwa konfliktu lub integracji relacji praca-rodzina, w: Zawodowe i zdrowotne problemy człowieka w różnych okresach dorosłości. Perspektywa psychologiczna, red. T. Rostowska, W. Budziński, Toruń 2012, s. 11-37.

Rozkrut D. (red.), Rocznik Demograficzny, Warszawa 2018. 
Ryś M., Wpływ dzieciństwa na późniejsze życie w małżeństwie i rodzinie. Studium psychologiczne. Część Il. Badanie empiryczne, Warszawa 1992.

Ryś M., Jakość i trwałość małżeństwa: propozycja skali, „Problemy Rodziny” 1994, nr 4, s. 19-24.

Ryś M., Wspólny system wartości w małżeństwie, „Powiernik Rodzin” 1997, nr 11.

Ryś M., Psychologia małżeństwa w zarysie, Warszawa 1999.

Ryś M., Wspieranie rozwoju osobowego w rodzinie, w: W trosce o rodzinę. W poszukiwaniu prawdy, dobra i piękna, red. M. Ryś, M. Jankowska, Warszawa 2007, s. 25-40.

Schwartz S.H., Universals in the content and structure of values: Theory and empirical tests in 20 countries, w: Advances in experimental social psychology. T. 25, red. M. Zanna, New York 1992, s. 1-65.

Schwartz S.H., Basic human values: Theory, measurement and application, „Revue Francaise de Sociologie" 2006, nr 4, s. 929-968.

Schwartz S.H, Cieciuch J., Vecchione M., Davidov E., Fischer R., Beierlein C., Ramos A., Verkasalo M., Lönnqvist J.E., Demirutku K., Dirilen-Gumus O., Konty M., Refining the theory of basic individual values, ,Journal of Personality and Social Psychology" 2012, nr 4, s. 663-688.

Spanier G.B., Measuring Dyadic Adjustment: New Scales for Assessing the Quality of Marriage and Similar Dyads, "Journal of the Marriage and the Family" 1976, nr 1, s. 15-28.

Spanier G.B., Lewis R.A., Marital Quality: a Review of the Seventies, „Journal of the Marriage and the Family" 1980, nr 4, s. 825-839.

Straś-Romanowska M., Późna dorosłość, w: Psychologia rozwoju człowieka. T. 2., red. B. Harwas-Napierała, J. Trempała, Warszawa 2011, s. 263-289.

Szczepańska H., Żony alkoholików, Warszawa 1992.

Śliwak J., Altruizm a preferencja wartości - badania empiryczne , „Roczniki Filozoficzne” 1996, nr 4, s. 111-146.

Śliwak J., Kruk M., Zarzycka B., Preferencja wartości a postawa wobec adopcji, w: Dalej w tę sama stronę: księga jubileuszowa dedykowana profesor Marii Braun-Gałkowskiej, red. I. Ulfik-Jaworska, A. Gała, Lublin 2012, s. 209-222.

Wolan-Nowakowska M., (2003). Praca zawodowa a jakość małżeńska, w: Psychologia w służbie rodziny, red. I. Janicka, T. Rostowska, Łódź 2003, s. 109-117.

\section{Preferencja wartości a jakość i trwałość małżeństwa. Badanie żon Anonimowych Alkoholików}

\section{Streszczenie}

Artykuł prezentuje powiązania systemu wartości i jakości oraz trwałości związków małżeńskich żon Anonimowych Alkoholików. W badaniach wykorzystano Portretowy Kwestionariusz Wartości S. Schwartza (PVQ-40; adaptowany w 2011 r. przez Cieciucha i Zaleskiego) oraz Skala Jakości i Trwałości Małżeństwa, autorstwa Ryś. Celem dokonania analiz korelacyjnych, uwzględniono odpowiedzi 286 żon Anonimowych Alkoholików. Prezentowane wyniki badań potwierdzają wszystkie hipotezy eksploracyjne - struktura systemu wartości żon AA jest powiązana z jakością i trwałością ich związków małżeńskich (wyłączając stymulację).

Słowa kluczowe: system wartości, jakość i trwałość małżeństwa, żony Anonimowych Alkoholików, współuzależnienie 


\section{Value preference and the quality and durability of marriage. A study of wives of members of the Alcoholics Anonymous}

\section{Summary}

The article presents the connections of the structure of value systems of the members of Alcoholics Anonymous wives and the quality and durability of their marriages. The studies make use of: Portrait Values Questionnaire by Schwartz (PVQ-40, adapted in 2011 by Cieciuch and Zaleski) and the Scale of the Quality and Durability of Marriage by Ryś. In order to perform correlation analysis, answers of 286 wives of members of Alcoholics Anonymous were considered. The results presented here confirm all of the posed hypotheses - the structure of value systems of AA wives is connected to the quality and durability of their marriages (simulation excluded).

Keywords: value system, quality and durability of marriage, wives of members of Alcoholics Anonymous, codependence 